\title{
Pengembangan Media Papan Flanel Untuk Memfasilitasi Konsep Bilangan Anak Pada Kelompok B
}

\author{
Cucu Mulyati', Dindin Abdul Muiz L², Taopik Rahman ${ }^{3}$ \\ Program Studi Pendidikan Guru Pendidikan Anak Usia Dini \\ Fakultas Ilmu Pendidikan \\ UPI Kampus Tasikmalaya \\ Email:cmulyati26@gmail.com
}

\begin{abstract}
Abstrak
Media pembelajaran adalah bagian terpenting dalam pelaksanaan pembelajaran di sekkolah. Studi pendahuluan di kelompok B TK Cendrawasih I dan TK Cendrawasih II ditemukan bahwa penggunaan media pembelajaran digunakan pada saat dibutuhkan saja. Media yang lebih praktis digunakan adalah spidol whiteboard dan papan tulis serta majalah untuk menyampaikan informasi terkait konsep bilangan. Padahal untuk anak usia dini lebih dibutuhkan media yang dapat digunakan secara langsung untuk melatih konsentrasi dan memberikan pengalaman baru bagi anak. Hasil identifikasi dan analisis masalah tersebut, peneliti menindak lanjuti dengan merancang media papan flanel sebagai solusi dalam memfasilitasi kemampuan konsep bilangan anak pada kelompok B. Dalam penelitian ini menggunakan metode Design Based Research (DBR) yang dikembangkan oleh Reeves untuk merancang, mengembangkan, dan menguji kelayakan suatu produk untuk mengatasi masalah dalam pembelajaran. Produk dirancang menggunakan bahan utama duplek cokelat dan kain flanel. Subjek penelitian adalah guru serta anak kelompok B TK Cendrawasih I dan TK Cendrawasih II. Pengumpulan data dilakukan dengan wawancara, validasi ahli, penilaian guru, observasi perlakuan anak selama penggunaan produk, dan dokumentasi. Rancangan produk dinyatakan layak oleh validator ahli, kemudian melakukan revisi sesuai saran dan dilakukan implementasi pada sekolah tempat penelitian. Implementasi produk dilakukan pada kelompok B TK Cendrawasih I dan Kelompok B TK Cendrawasih II. Secara umum produk dinyatakan layak digunakan sebagai media pembelajaran tentang konsep bilangan berdasarkan penilaian guru dan hasil observasi perlakuan anak terhadap produk. Refleksi dari pengembangan produk, yaitu menghasilkan media papan flanel untuk memfasilitasi kemampuan konsep bilangan anak pada kelompok B.
\end{abstract}

\section{Kata Kunci: Media Pembelajaran, Media Papan Flanel, Konsep Bilangan}

\begin{abstract}
Learning media are the most important part of implementing school learning. A preliminary study in group B of the Cendrawasih I Kindergarten and TK Cendrawasih II found that the use of learning media was used when needed. More practical media used aremarkers whiteboard and blackboardand magazines to convey information related to the concept of numbers. Whereas for early childhood more media is needed which can be used directly to practice concentration and provide new experiences for children. The results of identification and analysis of the problem, researchers followed up by designing flannel board media as a solution in facilitating the ability of the concept of child numbers in group B. In this study using the method of Design Based Research (DBR) developed by Reeves to design, develop, and test feasibility a product to overcome problems in learning. The product is designed using the main ingredients of brown duplex and flannel cloth. The research subjects were teachers and children in group B of Cendrawasih I Kindergarten and TK Cendrawasih II. Data collection is done by interviews, expert validation, teacher assessment, observation of child treatment during product use, and documentation. The product design was declared feasible by the expert validator, then revised
\end{abstract}


according to suggestions and carried out the implementation of the school where the research was conducted. Product implementation was carried out in group B of Cendrawasih I Kindergarten and Group B of TK Cendrawasih II. In general, the product is declared feasible to be used as a learning medium about the concept of numbers based on the teacher's assessment and observations of the child's treatment of the product. Reflections on product development, namely to produce flannel board media to facilitate the ability to conceptualize child numbers in group B.

\section{Keywords : Learning Media, Flannel Board Media, Number Concepts}

\section{PENDAHULUAN}

Sistem Pendidikan Nasional Nomor 20 Tahun 2003 menyatakan bahwa anak usia dini adalah anak yang berada pada rentang usia 0-6 tahun. Pada usia ini biasanya sering disebut masa golden age atau masa keemasan yang sangat penting untuk mengoptimalkan pertumbuhan dan perkembangannya. Pada masa inilah anak mengalami kematangan fisik dan psikis agar siap merespon stimulus yang didapatkan dalam kehidupannya.

Aspek yang harus dikembangkan dari anak usia dini menurut Peraturan Menteri Pendidikan dan Kebudayaan Nomor 137 tentang Standar Nasional PAUD ada enam aspek yang harus dikembangkan, yang terdiri dari perkembangan agama dan moral, perkembangan fisik motorik, perkembangan kognitif, perkembangan sosial emosional, perkembangan bahasa dan perkembangan seni dimana keenam aspek perkembangan tersebut saling terintegrasi dan saling mendukung. Salah satu aspek perkembangan yang perlu mendapatkan stimulus dengan baik yaitu perkembangan kognitif. Kognitif adalah proses berpikir yaitu kemampuan seseorang untuk menghubungkan, menilai, dan mempertimbangkan suatu kejadian atau peristiwa. oleh sebab itu, masa perkembangan anak usia dini harus di manfaatkan sebaik mungkin dan memberikan pendidikan yang sesuai dengan perkembangannya.

Pendidikan anak usia dni (PAUD) merupakan salah satu jenjang pendidikan yang dilaksanakan sebelum anak memasuki jenjang pendidikan selanjutnya. Pendidikan anak usia dini yang tercantum dalam Undang-undang Nomor 20 Tahun 2003 Pasal 1 ayat (14) “ suatu upaya pembinaan yang ditujukan kepada anak sejak lahir sampai dengan usia enam tahun yang dilakukan melalui

pemberian rangsangan pendidikan yang membantu pertumbuhan dan perkembangan jasmani dan rohani agar anak memiliki kesiapan dalam memasuki pendidikan lebih lanjut".

Pelaksanaan pembelajaran di PAUD pada hakikatnya harus menciptakan suasana yang menyenangkan, aman, dan nyaman untuk untuk membantu pertumbuhan dan perkembangan anak. Salah satu lingkup perkembangan yang harus dicapai pada tingkat pencapaian perkembangan anak usia 5-6 tahun adalah Kemampuan perkembangan kognitif yang terdiri dari pengetahuan umum dan sains, konsep bentuk, warna, ukuran dan pola, konsep bilangan dan lambang bilangan. Kemampuan ini dapat dilihat dari kemampuan anak dalam mengenal konsep bilangan, menghitung pada batas tertentu bahkan mengenal penambahan dan pengurangan secara sederhana. Konsep bilangan juga merupakan merupakan awal dalam pengenalan matematika kepada anak dan menjadi dasar pembelajaran matematika selanjutnya. Seorang guru diharapkan dapat untuk membantu mengembangkan potensi matematika anak sejak dini supaya dapat berkembang secara optimal. Oleh sebab itu kemampuan dasar matematika perlu dirangsang dan dikembangkan sejak dini.

Dari uraian di atas, peneliti mengangkat salah satu komponen yang harus disesuaikan dengan kondisi dan lingkungan anak yaitu media pembelajaran karena dirasa perlu dan akan memberikan proses pembelajaran yang efektif agar tercapai tujuan pembelajaran yang diharapkan. Begitupun dikemukakan oleh Santyasa (2007, hlm.

3) bahwa "media pembelajaran adalah segala sesuatu yang dapat digunakan untuk menyalurkan pesan (bahan pembelajaran), sehingga dapat menstimulus perhatian, minat, pikiran, dan perasaan siswa dalam kegiatan belajar untuk mencapai tujuan belajar".

Media pembelajaran merupakan bagian penting dalam proses pembelajaran untuk menyampaikan informasi kepada anak terkait pengetahuan yang tidak diketahui anak sebelumnya. Media yang digunakan harus memenuhi syarat media yang baik diantaranya terkandung nilai pendidikan, menarik bagi anak, aman untuk digunakan serta warna, ukuran dan bentuk disesuaikan dengan tahap perkembangan anak dan bertujuan untuk mengembangkan kemampuan anak.

Media papan flanel merupakan salah satu media yang dapat digunakan dalam proses 
pembelajaran di TK. Papan flanel adalah papan berlapis kain flanel dan gambar yang akan disajikan dapat dipasang dan dilepas dengan mudah serta dapat digunakan secara berturutturut. Papan flanel termasuk media pembelajaran dua dimensi yang dibuat dari kain flanel yang ditempelkan pada sebuah triplek, duplek maupun papan. Media papan flanel ini dapat digunakan untuk menyampaikan permainan konsep bilangan, pengenalan warna.

Berdasarkan hasil studi pendahuluan di kelompok B di TK Cendrawasih 1 dan TK Cendrawasih 2 yang berada di Kecamatan Cihaurbeuti, Kabupaten Ciamis. Peneliti menemukan masalah pada pembelajaran mengenai konsep bilangan. Terdapat beberapa media pembelajaran seperti poster angka dan tempelan angka lainnya pada dinding kelas kelompok B, tetapi menurut pernyataan guru media digunakan pada saat dibutuhkan saja sebagai penunjang proses pembelajaran karena media yang lebih praktis yaitu membagikan majalah kepada setiap anak serta menggunakan spidol whiteboard dan papan tulis yang sering digunakan untuk menyampaikan informasi.

\section{Perkembangan Kognitif}

Jean Piaget merupakan salah satu tokoh pertama yang merumuskan teori perkembangan kognitif. Teori perkembangan kognitif Jean Piaget adalah salah satu teori yang menjelasakan bagaimana anak beradaptasi dengan lingkungan dan menginterpretasikan objek dan kejadian- kejadian sekitarnya.Piaget menyatakan bahwa perkembangan kognitif adalah proses interaksi yang berlangsung antara anak dan pandangan perseptualnya terhadap sebuah benda atau kejadian di suatu lingkungan (Allen, 2010, hlm. 29).

2. Kognitif adalah suatu proses berpikir, yaitu kemampuan individu untuk menghubungkan, menilai, dan mempertimbangkan suatu kejadian atau peristiwa". Jadi, proses kognitif berhubungan dengan tingkat kecerdasan (intellegence) yang menandai seseorang dengan berbagai minat terutama sekali ditujukan kepada ide-ide dan belajar (Susanto, 2014, hlm.47). Piaget mengemukakan usia 5-6 tahun ini merupakan pra- operasional konkret. Pada tahap ini anak dapat memanipulasi objek simbol, termasuk kata-kata yang merupakan karakteristik penting dalam tahapan ini (Susanto, 2014, hlm. 50) Alfred Binet mengemukakan potensi kognitif seseorang tercermin dalam kemampuannya menyelesaikan tugas-tugas yang menyangkut pemahaman dan penalaran. Perwujudan potensi kognitif manusia harus dimengerti sebagai suatu aktivitas atau perilaku kognitif yang pokok, terutama pemahaman penilaian dan pemahaman baik yang menyangkut kemampuan berbahasa maupun yang menyangkut kemampuan motorik (Susanto, 2014, hlm. 51)

3. Dari pemaparan di atas dapat disimpulkan bahwa perkembangan kognitif adalah perkembangan yang berasal dari pikiran. Pikiran adalah bagian dari berpikirnya otak, otak merupakan bagian yang digunakan untuk fungsi pemahaman, pengertian, pengetahuan, dan penalaran Semakin berkembang pemikiran anak, maka akan semakin cerdas pada proses perkembangan selanjutnya.

4. Urgensi Perkembangan Kognitif

5. Pada dasarnya pengembangan kognitif dimaksudkan agar anak mampu melakukan eksplorasi terhadap dunia sekitar melalui panca inderanya. Adapun proses kognisi meliputi berbagai aspek, seperti persepsi, ingatan, pikiran, simbol, penalaran, dan pemecahan masalah.

Sehubungan dengan hal ini Piaget (dalam Susanto, 2014, hlm. 48) mengemukakan bahwa pentingnya guru mengembangkan kognitif pada anak, adalah:

Agar anak mampu mengembangkan daya persepsinya berdasarkan apa yang dilihat, didengar dan dirasakan, sehingga anak akan memiliki pemahaman yang utuh dan komprehensif;

Agar anak mampu melatih ingatannya terhadap semua peristiwa dan kejadian yang pernah dialaminya; Agar anak mampu mengembangkan pemikiran-pemikirandalam rangka menghubungkan satu peristiwa dengan peristiwa lainnya; Agar anak mampu memahami simbol-simbol yang tersebar di dunia sekitarnya;

Agar anak mampu melakukan penalaranpenalaran, baik yang terjadi secara alamiah (spontan), maupun melalui proses ilmiah (percobaan);

Agar anak mampu memecahkan persoalan hidup yang dihadapinya, sehingga pada akhirnya anak akan menjadi individu yang mampu menolong dirinya sendiri.

\section{Pembelajaran Matematika untuk Anak Usia Dini}

\section{A. Pengertian Matematika}

Kata matematika berasal dari perkataan Latin mathematika yang mulanya diambil dari perkataan Yunani mathematike yang berarti 
mempelajari.

Matematika untuk anak usia dini merupakan sarana yang dapat digunakan untuk mengembangkan kemampuan berpikir, mendorong anak untuk mengembangkan berbagai potensi intelektual yang dimilikinya serta dapat dijadikan sebagai sarana untuk menumbuhkan berbagai sikap dan perilaku positif dalam rangka meletakkan dasar-dasar kepribadian sedini mungkin seperti sikap kritis, ulet, mandiri, ilmiah, rasional dan lain sebagainya. Matematika bagi anak usia dini merupakan salah satu cara bagi anak untuk memahami dunia dan pengalaman- pengalaman yang dilakukannya serta upaya untuk memecahkan berbagai permasalahan yang ditemuinya setiap hari (Sriningsih, 2009, hlm.23).

Pembelajaran Konsep Bilangan di TK

Sudaryanti (dalam Ulum, 2014, hlm.14) mengemukakan bahwa "konsep bilangan merupakan konsep matematika yang sangat penting untuk dikuasai oleh anak, karena akan menjadi dasar bagi penguasaan konsep-konsep matematika selanjutnya". Selanjutnya menurut Busthomi (2012, hlm.105) menjelaskan tentang konsep bilangan yang merupakan dasar matematika yang terdiri dari menghitung bilangan, hubungan satu ke satu, menghitung jumlah, membandingkan serta mengenal simbol yang dihubungkan dengan jumlah benda.

Menurut Hartnett \& Gelman (dalam Seefeldt \& Wasik 2008, hlm.392) konsep bilangan mencakup pengembangan rasa kuantitas dan pemahaman kesesuaian lawan satu. Pengenalan konsep bilangan pada anak usia dini menurut Lestari (2011, hlm.105) dapat dilakukan melalui tiga tahap, yaitu: (1) membilang, yaitu menyebutkan bilangan berdasarkan urutan, (2) mencocokan setiap angka dengan benda yang sedang dihitung, (3) membandingkan antara kelompok benda satu dengan kelompok benda yang lain untuk mengetahui jumlah benda yang lebih banyak, lebih sedikit, atau sama.

\section{B. Kemampuan Konsep Bilangan Anak}

Dalam ranah pendidikan anak usia dini, matematika menjadi bagian penting dalam proses pembelajaran. Matematika merupakan komponen dalam ranah kognitif pada lembaga pendidikan anak usia dini. Anak-anak pada usia dini mulai membentuk pengetahuan tentang angka, operasi bilangan dan konsep matematika (Oates \& Robinson, 2012).

Berbeda dengan Seefeldt \& Wasik (2008 hlm.385) yang menyatakan bahwa anak usia 3-5 tahun sedang mengalami perubahan dan perkembangan yang sangat cepat dalam berpikir dan bernalar. Perubahan tersebut memungkinkan anak untuk memahami konsep-konsep matematika dengan cara baru. Anak-anak mulai berpikir tentang simbol/lambang, memahami kelestarian bilangan, dan berpikir secara semilogis. Selanjutnya, Brendefur, et al. (2013) menyatakan bahwa pengembangan matematika awal untuk anak usia dini terdiri dari empat area pokok yang meliputi: konsep bilangan, penafsiran hubungan, pengukuran, dan konsep ruang. Kepekaan terhadap konsep bilangan merupakan pondasi awal dalam kecerdasan matematika, dan kepekaan terhadap konsep bilangan pada anak berkembang sebelum usia sekolah. Berdasarkan pernyataan diatas maka dapat diketahui pentingnya mengenalkan konsep bilangan sejak usia dini.

Lembke \& Foegen (2009) untuk mengetahui tingkat kemampuan mengenal konsep bilangan pada anak usia dini dapat digunakan empat indikator. Keempat indikator tersebut meliputi: kemampuan membandingkan bilangan, (2) membilang benda, (3) mengurutkan lambang bilangan, dan (4) menyebutkan nama dari lambang bilangan.

\section{Manfaat Pembelajaran Konsep Bilangan}

Manfaat pembelajaran konsep bilangan yang diberikan pada kegiatan belajar di TK (Sujiono, dkk, 2008, hlm. 11) adalah:

Membelajarkan anak berdasarkan konsep bilangan yang benar, menarik, dan menyenangkan.

Menghindari ketakutan terhadap matematika sejak awal.

Membantu anak belajar matematika secara alami melalui kegiatan permainan konsep bilangan.

\section{Konsep Media Pembelajaran}

\section{A. Pengertian Media}

Kata media berasal dari bahasa latin yang mempunyai arti sebagai bentuk jam dari kata "medium" yang secara harfiah berarti "perantara" atau pengantar. Heinich, dkk (dalam Nurseto, 2011, hlm. 20) mengartikan istilah media sebagai "the term refer to anything that carries information between a source and a receiver". Berdasarkan definisi tersebut, dapat dikatakan bahwa proses pembelajaran merupakan proses komunikasi antara guru (source) dengan siswa (receiver) dan media sebagai alat penyampai pesannya.

\section{B. Media Papan Flanel}

Koyo K,dkk (dalam Anas 2014, hlm. 24)

Papan flanel adalah papan yang berlapis kain flanel sehingga gambar yang akan 
disajikan dapat dipasang, dilipat dan dilepas dengan mudah dan dapat dipakai berkali-kali. Papan flanel termasuk salah satu media pembelajaran dua dimensi, yang dibuat dari kain flanel yang ditempelkan pada sebuah tripleks atau papan atau gabus. Kemudian membuat guntingan-guntingan flanel atau kertas rempelas yang diletakkan di bagian belakng gambar.

Media papan flanel adalah media grafis yang efektif sekali untuk menyajikan pesan- pesan tertentu kepada sasaran tertentu pula. Papan flanel ini dapat menggunakan kain atau kertas palno secara berlapis. Papan flanel tersedia dalam berbagai variasi warna, murah dan mudah didapat.

Kelebihan menggunakan papan flanel adalah: a) gambar-gambar dengan mudah ditempelkan; b) efisiensi waktu dan tenaga; c) menarik perhatian peserta didik; d) memudahkan guru menjelaskan materi pelajaran. Adapun kelemahan menggunakan papan flanel yaitu antara lain: a) memerlukan waktu lama untuk mempersiapkan materi; b) memerlukan biaya yang mahal untuk mempersiapkannya; c) sukar menampilkan pada jarak yang jauh; dan d) flanel/laken mempunyai daya rekat yang kurang kuat.

\section{METODOLOGI PENELITIAN}

Metode penelitian yang digunakan dalam penelitian ini adalah Design Based Research (DBR). Penelitian ini dilaksanakan untuk mengembangkan prototype dalam pembelajaran konsep bilangan pada kelompok B.

Penelitian yang akan dilaksanakan oleh peneliti berkaitan dengan aspek-aspek yang sesuai dengan tahapan penelitian dari metode DBR, yaitu mengidentifikasi masalah yang terjadi di lapangan, memberi solusi terhadap masalah yakni berupa media papan flanel, melakukan uji coba lebih dari satu kali sampai menjadi media yang layak untuk dibuat, kemudian melakukan evaluasi dan meneliti tentang implikasi yang diberikan oleh media pembelajaran papan flanel untuk memfasilitasi kemampuan konsep bilangan anak pada kelompok B.

Borg \& Gall (dalam Nursyahidah, t.t) mengemukakan empat ciri utama penelitian dan pengembangan, yaitu:

1) Studying research findings pertinent to the product to be develop, artinya melakukan studi atau penelitian awal untuk mencari temuan-temuan penelitian terkait dengan produk yang akan dikembangkan.

1) Developing the product base on this findings, artinya mengembangkan produk berdasarkan temuan penelitian tersebut.

2) Field testing it in the setting where it will be used eventually, artinya dilakukannya uji lapangan dalam seting atau situasi nyata di mana produk tersebut akan digunakan.

3) Revising it to correct the deficiencies found in the field-testing stage, artinya melakukan revisi untuk memperbaiki kelemahankelemahan yang ditemukan dalam tahaptahap uji lapangan.

Berdasarkan penjelasan di atas, sebelum peneliti mengembangkan produk, terlebih dahulu peneliti melakukan studi pendahuluan sebagai langkah utama penelitian untuk mendapatkan informasi terkait masalah yang ditemukan. Dari hasil temuan yang diperoleh maka peneliti dalam hal ini membuat rancangan desain produk media papan flanel untuk memfasilitasi kemampuan konsep bilangan anak pada kelompok B yang selanjutnya di validasi oleh ahli dan diujicobakan secara langsung ke lapangan, dievaluasi, serta dilakukannya perbaikan apabila masih ada kekurangan sampai akhirnya produk tersebut layak untuk digunakan.

Pada tahap awal peneliti melakukan studi pendahuluan di TK Cendrawasih I dan II untuk mengetahui permasalahan yang terjadi ketika proses pembelajaran. Dari masalah yang ditemukan peneliti memberikan solusi untuk mengatasinya. Solusi yang diberikan cocok dalam mengatasi permasalahan penggunaan media dalam proses pembelajaran tentang konsep bilangan. Media yang dibuat peneliti adalah media papan flanel untuk memfasilitasi kemampuan konsep bilangan anak pada kelompok B. Sehingga anak terbantu dengan media yang akan dikembangkan peneliti. Selanjutnya peneliti membuat rancangan desain produk yang akan dikembangkan. Peneliti menghubungkan dengan teori-teori dan konsep sesuai dan mendukung dalam pengembangan media papan flanel untuk memfasilitasi kemampuan konsep bilangan anak pada kelompok B. Kemudian setelah peneliti membuat rancangan desain produk dan melakukan validasi terhadap ahli yang berpengalaman dan keilmuan sesuai dengan bidangnya mengenai media pembelajaran kemudian melakukan uji coba ke lapangan yaitu sekolah tempat penelitian. Validasi yang diberikan berupa pernyataan dan lembar validasi yang berisi aspek-aspek yang berkaitan dengan Standar Kompetensi (SK), Kompetensi Dasar $(\mathrm{KD})$, indicator, materi pembelajaran, tampilan 
papan flanel, bahan yang digunakan untuk media pembelajaran papan flanel serta hal dalam pembelajaran. Tahap selanjutnya yaitu dilakukan uji coba ulang produk untuk menindaklanjuti revisi produk sebelumnya dibuat. Apabila produk yang dibuat masih terdapat kekurangan, selanjutnya dilakukan revisi kembali supaya kekurangan yang terjadi sebelumnya dapat dievaluasi sehingga pada akhirnya menghasilkan sebuah produk media pembelajaran papan flanel yang siap digunakan dan sesuai harapan.

Partisipan yang terlibat dalam penelitian ini yaitu guru dan anak kelompok B TK Cendrawasih I dan TK Cendrawasih II sebagai subjek penelitian. Penelitian dilaksanakan di dua sekolah yaitu TK Cendrawasih I dan TK Cendrawasih II. Teknik pengumpulan data pada penelitian ini yaitu dengan teknik wawancara yang dilakukan kepada guru kelompok B dua skolah penelitian. Selanjtunya dengan teknik judgment expert yang melibatkan para ahli. Penelitian ini melibatkan ahli bidang matematika, ahli media pembelajaran dan ahli pedagogik. Berdasarkan validasi yang dilakukan oleh ahli akan menunjukan media pembelajaran yang disusun peneliti memiliki kekurangan dan kelebihan. Selanjutnya peneliti akan melakukan perbaikan dan revisi jika produk masih memilki kekurangan. Produk yang direvisi dilakukan sesuai saran dan masukan yang diberikan oleh para ahli.

Teknik selanjutnya yaitu lembar penilaian guru yang berguna untuk mengetahui respon terhadap produk yang sudah dibuat peneliti apakah layak digunakan pada saat uji coba di lapangan. Kemudian teknik observasi dijadikan teknik pengumpulan data dengan cara mengamati penggunaan media papan flanel untuk memfasilitasi kemampuan konsep bilangan anak pada kelompok B berdasarkan tanggapan guru serta respon anak dalam menggunakan produk kemudian melakukan dokumentasi untuk memperoleh data pada saat penelitian sebagai butkti yang akurat dari hasil observasi dan wawancara yang dilakukan.

Analisis data data merupakan proses mencari dan menyusun data secara sistematis berdasarkan hasil observasi. Analisis data dalam penelitian kualitatif dilakukan sejak sebelum memasuki lapangan, selama di lapangan dan setelah selesai di lapanngan. Dengan langkah-langkah berikut ini: 1) Reduksi Data, 2) Penyajian Data, 3) Penarikan Kesimpulan dan Verifikasi

\section{HASIL PENELITIAN DAN PEMBAHASAN}

Penelitian ini menggunakan pendekatan kualitatif dengan metode Design Based Research (DBR) yang bertujuan untuk membahas temuan data dilapangan berupa permasalahan yang dihadirkan dengan solusi berdasarkan rumusan masalah yang telah dibuat. Dari hal tersebut, peneliti akan membahas tentang hasil identifikasi dan analisis masalah berkaitan dengan kebutuhan dasar akan penggunaan media pembelajran untuk memfasilitasi kemampuan konsep bilangan, menjelaskan rancanagan media papan flanel, menjelaskan uji coba media papan flanel dalam pembelajaran, dan menjelaskan refleksi hasil uji coba media papan flanel untuk memfasilitasi kemampuan konsep bilangan anak pada kelompok B.

1. Rancangan Media Papan Flanel untuk Memfasilitasi Kemampuan Konsep Bilangan Anak pada Kelompok B Perkembangan media papan flanel untuk

memfasilitasi kemampuan konsep bilangan anak didasarkan dari hasil identifikasi dan hasil analisis masalah yang dikemukakan oleh peneliti di sekolah TK Cendarawasih I dan TK Cendrawasih II pada guru kelompok B. Berdasarkan dari hasil wawancara dua guru kelompok B tersebut, didapatkan sebuah masalah terkait materi tentang konsep bilangan dan ketersediaan media yang sangat terbatas. Padahal untuk anak usia dini lebih mudah apabila belajar melalui benda konkrit, oleh sebab itu untuk memfasilitasi anak dalam pembelajaran tentang konsep bilangan membutuhkan media yang bisa dimainkan secara langsung untuk menumbuhkan rasa ingin tahu anak. Pada proses pembelajaran lebih sering menggunakan spidol whiteboard dan papan tulis untuk menyampaikan informasi

terkait dengan materi tentang konsep bilangan. Peneliti mengidentifikasi dan menganalisis permasalahan yang ada pada kelompok B TK Cendrawasih I dan TK Cendrawasih II dengan merancang sebuah media pembelajaran berupa papan flanel, untuk dijadikan sebuah solusi permasalahan terkait dengan kemampuan konsep bilangan pada anak kelompok B.

\section{Proses Pembuatan Media Papan Flanel untuk Memfasilitasi Kemampuan Konsep Bilangan Anak pada Kelompok B \\ Pada proses pembuatan produk media papan} flanel diawali dengan menganalisis kurikulum 2013 PAUD. Analisis kurikulum meliputi Kompetensi Inti, Kompetensi Dasar, indikator pencapaian perkembangan, tujuan pembelajaran, materi dan media pembelajaran untuk memfasilitasi kemampuan konsep bilangan. 
Selanjutnya peneliti membuat dasar pengembangan produk yang merupakan ide dasar atau gambaran umum dari media yang akan diaplikasikan, serta membuat story board yang berisi desain dari media yang akan dibuat peneliti. Papan flanel adalah papan yang berlapis kain flanel sehingga gambar yang disajikan dapat dipasang, dilipat, dan dilepas dengan mudah dan juga dapat dilakukan berkali-kali. Papan flanel merupakan salah satu media pembelajaran dua dimensi. Peneliti menggunakan duplek coklat tebal sebagai bahan yang digunakan untuk papan flanel. Kemudian duplek tersebut dilapisi dengan kain flanel berwarna biru dan papan flanel diberi perekat. Perekat ini digunakan untuk menempelkan gambaar objek pada papan flanel. Objek yang digunakan dalam penelitian ini yaitu kartu angka dari 1 sampai 10 kemudian benda (buah apel) dan kartu nama bilangan dari 1 sampai 10 yang dengan mudah dapat dipasang dan dilepas.

Produk ini dibuat dari bahan utama yaitu duplek tebal, duplek tipis dan kain flanel. Duplek tebal digunakan untuk membuat papan flanel kemdudian dilapisi dengan kain flanel dan duplek tipis digunakan untuk membuat kartu angka dan kartu nama bilangan yang selanjutnya dilapisi kain flanel dan pada bagian permukaan kartu angka ditempelkan angka yang sudah disiapkan dari kain flanel, serta untuk permukaan kartu bilangan ditempelkan nama bilangan 1 sampai 10 yang sudah dicetak dan dilaminasi . kain flanel juga digunakan untuk membuat benda yang mendukung pada media papan flanel yaitu tiruan buah apel. Kain flanel diberi pola buah apel kemudian dijahit dan diisi oleh dakron seolaholah menjadi apel yang nyata. Semua komponen yang mendukung media papan flanel memicu rasa ingin tahu anak dan menarik di mata anak.

Setelah produk selesai dirancang dan dibuat, tahap selanjutnya yakni melakukan validasi produk oleh validator ahli yang menilai kelayakan produk yang telah dibuat peneliti sebelum dilakukan uji coba ke sekolah penelitian. Pada tahap validasi dilakukan oleh tiga validator ahli, yaitu ahli dalam bidang matematika yang mengkaji dan menganalisis tentang konten media pembelajaran papan flanel dalam pembelajaran tentang konsep bilangan, ahli dalam bidang media pembelajaran mengkaji dan menganalisis tentang keseluruhan media pembelajaran yang telah dirancang, dibuat, dari segi bahan, tampilan, dna kesesuaian media dengan konteks pembelajaran tentang konsep bilangan, dan ahli dalam bidang pedagogik mengkaji dan menganalisis dari segi kebermanfaatan serta kesesuaian dengan media pembelajaran untuk anak pada kelompok B.
Validator ahli menyatakan media papan flanel cukup baik dan layak diuji cobakan ke skolah penelitian setelah memperbaiki sesuai dengan saran dan rekomendasi yang telah diberikan. Hasil dari perbaikan dan revisi produk, selanjutnya diuji cobakan di sekolah temoat penelitian.

\section{Implementasi Media Papan Flanel untuk Memfasilitasi Kemampuan Konsep Bilangan Anak Pada Kelompok B .}

Proses uji coba media papan flanel untu dilakukan dalam dua tahap yaitu uji coba produk tahap I dan uji coba produk tahap II yang dilakukan di TK Cendrawasih I dan TK Cendrawasih II. Uji coba tahap 1 dilakukan pada kelompok B TK Cendrawasih 1, yang berjumlah 15 orang. Hasil dari uji coba 1 yaitu guru menanggapi bahwa media papan flanel dinilai sudah bagus dan layak digunakan sebagai media pembelajaran dalam memfasilitasi kemampuan konsep bilangan anak. Berdasarkan hasil pengamatan, anak-anak kelas B dalam penggunaan media papan flanel ini terlihat sangat bersemangat dan antusias saat menggunakan produk dalam proses pembelajaran. pada indikator menyebutkan bilangan 1 sampai 10, enam orang atau $40 \%$ termasuk ke dalam kategori Berkembang Sesuai Harapan (BSH) dan sembilan orang anak atau $60 \%$ termasuk dalam kategori Berkembang Sangat Baik (BSB) Sedangkan pada indikator mencocokan bilangan dengan lambang bilangan sebanyak tujuh orang atau $47 \%$ termasuk ke dalam kategori Berkembang Sesuai Harapan, dan delapan orang anak atau $53 \%$ termasuk ke dalam kategori Berkembang Sangat Baik (BSB).

Setelah uji coba tahap I dan dilakukan revisi peneliti melakukan uji coba tahap II di kelompok B TK Cendrawasih II, jadi pada uji coba tahap II anak yang menjadi subjek penelitian berjumlah 13 orang anak. Hasil dari uji coba tahap II guru memberikan tanggapan agar dalam proses penyampaian pembelajaran lebih baik lagi supaya suasana di dalam kelas lebih kondusif. Sedangkan penilaian guru terhadap media pembelajaran papan flanel secara keseluruhan sudah bagus dan memenuhi standar aspek-aspek yang tertera dalam instrumen penilaian guru yang diberikan peneliti. Banyak keuntungan yang guru peroleh dari penggunaan media papan flanel, lebih efisien, menyenangkan dan meningkatkan motivasi belajar pada anak. pada indikator menyebutkan bilangan 1 sampai 10 , lima orang atau $39 \%$ termasuk ke dalam kategori Berkembang Sesuai Harapan (BSH) dan delapan orang anak atau $61 \%$ termasuk dalam kategori Berkembang Sangat Baik (BSB) Sedangkan pada 
indikator mencocokan bilangan dengan lambang bilangan sebanyak empat orang atau $31 \%$ termasuk ke dalam kategori Berkembang Sesuai Harapan, dan sembilan orang anak atau 69\% termasuk ke dalam kategori Berkembang Sangat Baik (BSB).

Refleksi Hasil Uji Coba Media Papan Flanel Untuk Memfasilitasi Kemampuan Konsep Bilangan Anak pada Kelompok B. Tahap terakhir setelah melakukan uji coba produk yaitu refleksi dari pengembangan produk. Hasil refleksi produk merupakan produk akhir dari pengembangan media papan

flanel untuk memfasilitasi kemampuan konsep bilangan anak pada kelompok B. Media tersebut dapat menunjang pembelajaran tentang konsep bilangan, diantaranya menyebutkan, menunjukan, mencocokan bilangan dengan lambang bilangan dan produk inipun dikhususkan untuk anak kelompok B. Media papan flanel ini dirancang dengan perpaduan papan flanel yang menjadi tempat untuk menempelkan objek diantaranya lambang bilangan, benda, dan nama bilangan. Dengan adanya produk ini diharapkan menjadi

solusi dan alternatif dalam menyelesaikan masalah penggunaan media pembelajaran yang dapat memfasilitasi kemampuan konsep bilangan anak pada kelompok B.

Hasil akhir dari tahap pengembangan media papan flanel disebarkan secara terbatas di TK Cendrawasih I dan II sebagai alternatif pilihan media pembelajaran tentang konsep bilangan.

\section{SIMPULAN}

Berdasarkan dari hasil penelitian tentang pengembangan media papan flanel untuk memfasilitasi kemampuan konsep bilangan anak pada kelompok B didapatkan kesimpulan sebagai berikut:

1) Penggunaan media pembelajaran di sekolah yang di teliti, media digunakan apabila pada saat dibutuhkan saja serta disesuaikan dengan tema. Media pembelajaran untuk memfasilitasi kemampuan konsep bilangan anak hanya sebatas gambar-gambar yang menempel pada dinding kelas. Belum tersedianya media papan flannel khususnya untuk memfasilitasi kemampuan konsep belajar anakk. Padahal media pembelajaran yang menarik dapat meningkatkan minat belajar anak serta dapat meningkatkatkan hasil belajar anak.

1. Pengembangan media pembelajaran papan flannel untuk memfasilitasi kemampuan konsep bilangan anak ini dibuat berdasarkan dengan permasalahan yang peneliti temui saat melakukan studi pendahuluan terkait masalah yang ada di kelompok B. Didukung dengan studi literatur yang merupakan bagian dari pemecahan masalah agar mendapatkan solusi yang diharapkan. Kemudian peneliti melakukan pengembangan produk dengan menganalisis kurikulum, kemudian menyusun storyboard yang dibuat dengan menggunakan bahan utama duplek cokelat, kain flanel, lem lilin, kertas hvs, perekat, benang dan dakron. Selanjutnya membuat pola terlebih dahulu pada kain flannel untuk membuat konten untuk di temple pada papan flannel kemudian bungkus duplex cokelat coklat menggunakan kain flannel. Pada tahap selanjutnya adalah validasi terhadap produk

yang telah dibuat peneliti dengan melibatkan validator ahli sesuai dengan bidang keahlian masing- masing, yaitu validator ahli bidang matematika, ahli bidang media pembelajaran, dan ahli bidang pedagogik, sehingga setelah memiliki nilai kelayakan produk selanjutnya bisa dilakukan uji coba ke sekolah penelitian.

2) Proses implementasi/uji coba produk dilaksanakan sebanyak dua kali. Data yang didapatkan berupa penilaian guru dan perlakuan anak terhadap media papan flannel setelah digunakan pada saat pembelajaran. Dari hasil uji coba pertama yang menghasilkan kesan positif meskipun dalam uji coba pertama ini terdapat revisi produk dilakukan untuk memperbaiki kekurangan produk. Penilaian guru dan perlakuan anak yang ditunjukkan setelah menggunakan media papan flanel secara umum menyatakan bahwa produk berupa media papan flannel untuk memfasilitasi perkembangan kemampuan konsep bilangan pada kelompok B layak digunakan pada proses pembelajaran.

3) Setelah produk divalidasi oleh para ahli, melakukan uji coba untuk menguji kelayakan produk, maka refleksi dari pengembangan produk adalah menghasilkan produk akhir berupa media papan flannel untuk memfasilitasi perkembangan kemampuan konsep bilangan pada kelompok $\mathrm{B}$ yang dikemas dalam tas sehingga mudah untuk disimpan.

4)

DAFTAR PUSTAKA

Allen, Eileen, K., Marotz Lynn R. (2010). Profil Perkembangan Anak. Pra kelahiran 
sampai usia 12 tahun.

Anas, M. (2016). Alat Peraga dan Media Pembelajaran. Jakarta: PT. Raja Grafindo Persada. Herington, J., et. al. (2007). Design-based research and doctoral students: Guidelines for preparing a dissertation proposal.pdf.

Lambke, E., \& Foegen, A. (2009). Identifying Early Numeracy Indicators For Kindergarten And First-Grade Students. Learning Disabilities Research \& Practice, 24, 12-20.

Lestari KW. (2011). Konsep Matematika untuk Anak Usia Dini. Jakarta: Direktorat Pembinaan Pendidikan Anak Usia Dini.

Nurseto, T. (2011). Membuat media pembelajaran yang menarik. Jurnal Ekonomi \& Pendidikan. 8 (1), hlm. 19-35.

Peraturan Menteri Pendidikan Nasional. (2009). Peraturan Menteri Pendidikan Nasional Nomor 58 Tahun 2009 tentang Standar Pendidikan Anak Usia Dini. Jakarta: Depdiknas.

Seefeldt, C. \& Wasik, B.A. (2008). Pendidikan Anak Usia Dini Menyiapkan Anak Usia Tiga, Empat, Lima Tahun Masuk Sekolah.Jakarta: PT. Indeks.

Sriningsih, N. (2009). Pembelajaran Matematika Terpadu Untuk Anak Usia Dini. Bandung: Pustaka Sebelas

Sujiono, Yuliani Nurani, dkk. (2008). Metode Pengembangan Kognitif. Jakarta: Universitas Terbuka

Susanto, A. (2014). Perkembangan Anak Usia dini. Jakarta: PT. Kharisma Putra Utama.

Suyadi. (2010). Psikologi Belajar PAUD. Yogyakarta: Pedagogia.

Ulum, I. (2014). Peningkatkan Pemahaman Konsep Bilangan Melalui Permainan Memancing Angka Pada Anak. Yogyakarta: Univesitas Yogyaka 